УДК 347.121.2

DOI https:// doi.org/10.32837 / yuv.v0i3.1961

Ю. Бєлова,

аспірант

Хмельницького університету управління та права

\title{
ЗГОДА ТА ІНШІ ПІДСТАВИ ВИНИКНЕННЯ ЦИВІЛЬНИХ ПРАВОВІДНОСИН ЩОДО ПЕРСОНАЛЬНИХ ДАНИХ
}

\begin{abstract}
Постановка проблеми. Важливим елементом цивільних правовідносин щодо персональних даних виступають підстави ї виникнення, серед яких особливе місце посідає згода суб'єкта персональних даних. Інститут згоди суб'єкта персональних даних $€$ одним із виявів свободи людини у відносинах з приводу таких даних. Свобода суб'єкта персональних даних $є$ одночасно передумовою і наслідком згоди та забезпечує вплив суб'єкта персональних даних на їх обробку. Однак свобода суб'єкта персональних даних надавати чи не надавати згоду на ї обробку не є абсолютною, що підтверджується тим, що згода є далеко не єдиною підставою для їх обробки. Водночас згода $€$ не єдиною підставою для виникнення цивільних правовідносин щодо персональних даних.

У цивілістичних дослідженнях питання підстав виникнення цивільних правовідносин щодо персональних даних розкривається не досить. Більшість науковців розглядає це питання в контексті захисту особистих немайнових прав (В. Бобрик, О. Гуменюк, Н. Давидова, Л. Красицька, О. Кулініч, Р. Стефанчук, Н. Устименко, Л. Федюк) або інформаційних прав (О. Кохановська, А. Кодинець), лише незначна їх кількість стосується саме права на персональні дані (О. Дмитренко, I. Романюк).
\end{abstract}

Метою статті $€$ визначення підстав виникнення цивільних правовідносин щодо персональних даних.
Виклад основного матеріалу. Поняття «згода» носить загально-цивілістичне значення та виявляється в різних інститутах цивільного права. Очевидно, що питома вага використання поняття «згода» припадає на особисті немайнові права фізичної особи, що власне і розкриває іiі значення у відносинах 3 приводу персональних даних.

Найповніше концепція згоди розкрита в Загальному регламенті про захист даних [1], в якому наводиться визначення поняття «згода суб'єкта даних» (ст. 4), яка визнається підставою для законної обробки персональних даних (ст. 6), виокремлюється згода на обробку чутливих категорій даних (ст. 9). Ні міжнародні акти, ні національне законодавство не визначають правову природу згоди суб'єкта персональних даних, залишивши це питання предметом наукових досліджень.

Згода суб'єкта персональних даних має принаймні три вияви: 1) можливість фізичної особи діяти певним чином; 2) юридичний факт; 3) об'єктивована форма. Згоду як можливість суб'єкта персональних даних слід розглядати 3 точки зору трьох зрізів. По-перше, така згода $є$ важливим елементом права кожної людини на вільний розвиток своєї особистості. Так, концепція згоди базується на ліберальній доктрині свободи людини, iii гідності та недоторканості, грунтується на теорії фундаментальних прав людини, тісно переплітаючись із правом на приватність [2]. 
По-друге, згода суб'єкта персональних даних відображає таку загальну засаду цивільного законодавства як неприпустимість свавільного втручання у сферу особистого життя людини. У цьому контексті наявність чи відсутність згоди суб'єкта персональних даних вказує на правомірність чи неправомірність обробки персональних даних. Тобто, згода виконує функцію трансформації поведінки $з$ такої, що суперечить моральним засадам суспільства, в таку, що ї відповідає [3, с. 123].

Так, змінюються очікування особи, яка надає згоду (вона розуміє, чого очікувати відповідно до наданої згоди), особи, яка запитує згоди (вона розуміє, що ії поведінка вважається дозволеною), суспільства загалом (відбувається визнання впливу згоди на відносини між особою, яка надає згоду, та особою, яка їі запитує) [4, с. 172]. У нашому випадку втручання в особисте життя шляхом збирання, зберігання, використання і поширення відомостей про фізичну особу за наявності згоди такої особи трансформується у відносини між суб'єктом, володільцем i розпорядником персональних даних з приводу їх обробки. При цьому для того, щоб згода суб'єкта персональних даних виконувала таку функцію, вона повинна відповідати встановленим у законі вимогам щодо іiі змісту та форми.

По-третє, згоду суб'єкта персональних даних слід розглядати в контексті можливості фізичної особи на власний розсуд визначати свою поведінку у сфері приватного життя, тобто як елемент змісту особистого немайнового права. Оскільки персональні дані становлять невідчужуване особисте немайнове благо, юридичний зв'язок між суб'єктом права та його об'єктом існує протягом усього життя і не може вважатися розірваним через те, що індивід дозволив третій особі збирати, поширювати чи іншим чином використовувати такі дані [5, с. 103].
У цій площині поняття згоди тісно пов'язане з ідеєю контролю суб'єкта персональних даних над тим, хто, відповідно до якої мети та для яких цілей оброблятиме його персональні дані. Очевидно, що згода - не єдиний вияв контролю суб'єкта персональних даних. Цьому серед іншого також слугує вимога суб'єкта персональних даних із запереченням проти обробки персональних даних, вимога щодо зміни чи знищення власних персональних даних, а також відкликання згоди на обробку персональних даних. Однак усе це - різні механізми забезпечення контролю суб'єкта персональних даних на різних стадіях обробки персональних даних.

Таким чином, згоду суб'єкта персональних даних слід розглядати як вияв можливості вільно визначати свою поведінку в сфері особистого життя, яка спрямована на те, щоб уповноважити володільця персональних даних на їх подальшу обробку, та забезпечує контроль суб'єкта персональних даних за такою обробкою.

Згода суб'єкта персональних даних як юридичний факт слугує підставою для обробки таких даних. При цьому виникає принаймні два питання, на які немає однозначної відповіді ні в законодавстві, ні в правозастосовній практиці, ні в доктрині: чи є згода суб'єкта персональних даних правочином; чи застосовуються до згоди суб'єкта персональних даних вимоги про дійсність правочинів?

Якщо подивитися на ці питання ширше, принаймні на рівні згоди фізичної особи на втручання в їі особисті немайнові права, то стає очевидним, що відповіді будуть різними залежно від ситуаціі. Так, у літературі зазначається, що згода особи, яка виражає дозвіл на використання ознак індивідуальності, повинна вважатися правочином і може бути вчинена у вигляді як одностороннього, так i двостороннього правочину, на відміну від згоди пацієнта на здійснення медичного втручання, яка не 
визнається правочином [6, с. 144]. Буквальне тлумачення законодавства свідчить, що згода суб'єкта персональних даних має усі ознаки правочину: $є$ дією особи (добровільним волевиявленням фізичної особи), спрямованою на набуття, зміну або припинення цивільних прав та обов'язків (щодо надання дозволу на обробку іï персональних даних). Таким чином, згоду суб'єкта персональних даних слід віднести до односторонніх правочинів.

Згода суб'єкта персональних даних має ще одне, неочевидне на перший погляд значення. Розвиток інформаційних технологій і спричинені ним поява та поширення адресного маркетингу надали персональним даним комерційної цінності для суб’єктів підприємницької діяльності. У такій ситуації згода суб'єкта персональних даних не тільки виражає вибір фізичної особи щодо використання персональних даних іншою особою, але й забезпечує оборотоздатність економічної цінності персональних даних [7, с. 11].

Підтвердження цьому знаходимо навіть у преамбулі Загального регламенту про захист даних [1], яка вказує на дедалі частіше застосування обробки персональних даних у різних сферах соціальної та економічної діяльності, неминуче істотне збільшення транскордонних потоків персональних даних між усіма тими, хто бере участь в економічному і соціальному житті, необхідність розвитку обміну персональними даними між різними підприємствами (пп. 4, 5). У науковій літературі це пояснюється тим, що після надання суб'єктом згоди на обробку інформації про особу (в тому числі персональних даних) виникає віддільність інформації від фізичної особи, оскільки факт згоди суб'єкта на використання інформації про себе дає змогу виокремити інформацію від суб'єкта-носія, а це $є$ умовою для визнання такого об'єкта оборотоздатним.

Якщо особа надала згоду на обробку інформації про себе, то інформація отримує стан виокремленості від особи, однак використання отриманої інформації можливе в межах, дозволених особою. Отже, інформація про особу за наявності іiі волевиявлення може розглядатися як оборотоздатний об’єкт, оскільки цей вид інформації може мати економічний зміст, здатність до об'єктивного існування та віддільності від особи [8, с. 40]. Підтримуючи такий підхід, зауважимо, що згоду не слід розглядати як єдиний чинник відокремленості персональних даних від суб'єкта, оскільки обробка персональних даних можлива й 3 інших підстав. 3 цього приводу необхідним є співвідношення згоди 3 іншими підставами обробки персональних даних.

Закон України «Про захист персональних даних» і Загальний регламент про захист даних [1] називають по шість підстав для обробки персональних даних. Цей перелік підстав є вичерпним i не підлягає поширювальному тлумаченню. Крім того, передбачаються спеціальні підстави для обробки чутливих категорій даних: про расове або етнічне походження, політичні, релігійні або світоглядні переконання, членство в політичних партіях і професійних спілках, засудження до кримінального покарання, а також даних, які стосуються здоров'я, статевого життя, біометричних або генетичних даних (ч. 2 ст. 7 Закону та ч.ч. 6-9 Загального регламенту про захист даних [1]). Вказані у законі підстави відповідають нормам регламенту попри те, що ї дослівне формулювання, а подекуди і тлумачення при застосуванні, відрізняються. Дослідимо їх детальніше.

Традиційно підстави обробки персональних даних можна поділити на дві групи: незалежно від згоди особи та за згодою особи [9, с. 215]. Однак такий дихотомічний поділ не розкриває всієї специфіки підстав. Пропонуємо при поділі підстав на види використовувати як критерій не тільки наявність чи відсутність згоди, 
але й враховувати, в чиїх інтересах здійснюється обробка персональних даних. Це дає змогу виділити чотири види підстав:

1) обробка персональних даних здійснюється за згодою суб’єкта персональних даних;

2) обробка персональних даних здійснюється в інтересах суб'єкта персональних даних, але незалежно від згоди останнього (укладення та виконання правочину, стороною якого є суб'єкт персональних даних або який укладено на користь суб'єкта персональних даних чи для здійснення заходів, які передують укладенню правочину на вимогу суб'єкта персональних даних; захист життєво-важливих інтересів суб'єкта персональних даних);

3) обробка персональних даних здійснюється незалежно від згоди суб'єкта персональних даних для задоволення публічних інтересів (дозвіл на обробку персональних даних, наданий володільцю персональних даних відповідно до закону виключно для здійснення його повноважень; необхідність виконання обов'язку володільця персональних даних, передбаченого законом);

4) обробка персональних даних здійснюється в інтересах третіх осіб незалежно від згоди суб'єкта персональних даних за умови пропорційності такого втручання в його особисте життя (необхідність захисту законних інтересів володільця персональних даних або третьої особи, якій передаються персональні дані, крім випадків, коли потреби захисту основоположних прав і свобод суб'єкта персональних даних у зв'язку з обробкою його даних переважають такі інтереси).

Розкриваючи співвідношення згоди та інших підстав обробки персональних даних, слід зазначити таке. Попри те, що згода міститься в переліку підстав на першому місці, це не означає, що згода має переважаюче значення порівняно 3 іншими під- ставами. Більше того, кількість альтернативних згоді підстав обробки персональних даних дає підстави стверджувати, що значення згоди як вияву інформаційного самовизначення фізичної особи у відносинах з приводу персональних даних, дещо перебільшено [10, с. 241].

3 урахуванням мети забезпечення інтересів, за наявності яких допускається вчинення діянь із персональними даними без згоди особи, можна виділити такі випадки: 1) захист інтересів держави, безпеки громадян під час введення воєнного чи надзвичайного стану; 2) забезпечення сплати податків, зборів, інших обов'язкових платежів; 3) забезпечення інтересів судочинства 4) інтереси забезпечення виконавчого провадження; 5) мета - забезпечення цивільного обороту; 6) реалізація конституційних, цивільних прав громадян 7) розслідування злочинів; 8) мета доступ до публічної інформації та суспільно-необхідної інформації (інформації, яка викликає суспільний інтерес) [9, с. 217-221].

Якщо вести мову про цивільні правовідносини, то згода займає чільне місце серед підстав обробки персональних даних поряд із правочином і випадками, коли приватні інтереси володільця персональних даних або третьої особи, якій передаються персональні дані, переважають потреби захисту основоположних прав і свобод суб'єкта персональних даних.

Поряд із цим згода має ще одну відмінність від інших підстав обробки персональних даних. Усі інші підстави обробки персональних даних, крім згоди, обтяжені додатковою умовою - так званим тестом на необхідність. Тобто, обробка персональних даних буде вважатися правомірною, якщо вона $є$ необхідною для досягнення цілей, зумовлених у відповідній підставі. Якщо ж обробка персональних даних виходить за межі такої необхідності, то для іï здійснення вже потрібна згода суб'єкта персональних даних. 
Те, що згода як підстава обробки персональних даних не вимагає застосування тесту на необхідність, не означає, що згода надає володільцю персональних даних ширші можливості. Так, отримання згоди суб'єкта персональних даних не звільняє їх володільця від обов'язку дотримуватися загальних та особливих вимог до обробки персональних даних. Більше того, згода фізичної особи на обробку персональних даних не тягне за собою іï відмову від прав суб'єкта персональних даних чи звуження їх змісту. Так само згода на обробку персональних даних не позбавляє та не обмежує можливості захисту персональних даних.

На жаль, вітчизняний законодавець вказав на необхідність як умову обробки персональних даних лише щодо виконання передбаченого законом обов'язку володільця персональних даних та захисту законних інтересів володільця персональних даних або третьої особи, якій передаються персональні дані (п.п. 5, 6 ч. 1 ст. 11). 3 цього приводу вважаємо, що п.п. 2, 3,4 ч. 1 ст. 11 потребують змін шляхом закріплення необхідності як умови обробки персональних даних, а до внесення змін ці норми закону слід тлумачити обмежувально, із застосуванням тесту на необхідність обробки.

Від згоди як підстави для обробки персональних даних слід відрізняти випадки необхідності такої обробки, що виникає на стадії, яка передує укладанню правочину, під час укладання або виконання правочину стороною або третьою особою, на користь якої укладено цей правочин, є суб'єкт персональних даних. Спільним для цих підстав є те, що вони грунтуються на вільному волевиявленні суб'єкта персональних даних.

Як було встановлено вище, згода $€$ різновидом одностороннього правочину. При цьому є дві принципові відмінності. По-перше, правочин є підставою для обробки персональних даних незалежно від того, чи передбачає він дозвіл суб'єкта персональних даних на таку обробку. По-друге, обробка персональних даних на підставі правочину обмежена необхідність, яка виникає у зв'язку з укладанням або виконанням відповідного правочину. Також правомірність обробки персональних даних у цьому випадку залежить від правомірності самого правочину, від того, чи був він укладений, від його дійсності на момент такої обробки.

Необхідність обробки персональних даних в інтересах третіх осіб незалежно від згоди суб'єкта персональних даних за умови пропорційності такого втручання в його особисте життя (п. 6 ч. 1 ст. 11) є єдиною підставою, яка відповідно до законодавства вимагає дотримання балансу між колідуючими інтересами. Тобто, вимагається одночасна наявність двох умов: необхідність захисту законних інтересів володільця персональних даних або третьої особи, якій передаються персональні дані; такі інтереси переважають потреби захисту основоположних прав і свобод суб'єкта персональних даних у зв'язку з обробкою його даних. Прикладом вказаного законного інтересу у сфері захисту персональних даних може бути адресний (прямий) маркетинг, а саме просування товарів шляхом направлення комерційного повідомлення потенційним споживачам не $€$ правом, гарантованим законом, як і не заборонено ним [11, с. 68].

Розуміння балансу колідуючих інтересів у контексті цієї підстави обробки персональних даних було розкрито Судом $E C$ у справі «Національна асоціація кредитних фінансових установ (ASNEF) і Федерація електронної комерції і прямого маркетингу (FECEMD) проти Державної адміністраціï» (Asociacion Nacional de Establecimientos Financieros deCredito (ASNEF) and Federacion de Comercio Electronico y Marketing Directo (FECEMD) v. Administracion del Estado) від 24 листопада 2011 року [12].

Необхідно взяти до уваги, що баланс вказаних інтересів здебільшого залежить від індивідуальних особливостей 
конкретної справи, враховуючи те, що права суб'єкта персональних даних тісно пов'язані з фундаментальним правом на приватність. При цьому слід враховувати, що серйозність втручання у фундаментальні права суб'єкта персональних даних внаслідок їх обробки може відрізнятися залежно від того, чи отримали такі дані оприлюднення в загальнодоступних джерелах чи ні. Однак, за винятком чутливих даних, жодні інші персональні дані не можуть мати наперед визначеної переваги перед інтересами володільця персональних даних.

Співвідношення згоди 3 іншими підставами обробки персональних даних не завжди $є$ простим та очевидним. Наприклад, якщо володілець персональних даних обробляє їх у зв'язку із вчиненням та виконанням правочину, то для обробки цих даних для цілей, не пов'язаних із вчиненням та виконанням правочину, необхідна буде окрема згода суб'єкта персональних даних. Це демонструє необхідність деталізації умов правочину i на практиці означає, що для окремих етапів обробки персональних даних необхідно отримати згоду як додаткову підставу для такої обробки. У деяких випадках кілька підстав обробки персональних даних можуть застосовуватися одночасно. Іншими словами, будь-який етап обробки персональних даних повинен у будь-який час відповідати одній або кільком підставам для такої обробки [13].

Висновки. Підсумовуючи питання згоди та інших підстав виникнення цивільних правовідносин щодо персональних даних, необхідно наголосити на таких положеннях:

1. Згода суб'єкта персональних даних $€$ виявом можливості вільно визначати свою поведінку в сфері особистого життя, спрямовану на уповноваження володільця персональних даних на їх подальшу обробку, та забезпечує контроль суб'єкта персональних даних за їх обробкою.

2. Згода суб'єкта персональних даних має всі ознаки односторон- нього правочину: є дією особи (добровільним волевиявленням фізичної особи), спрямованою на набуття, зміну або припинення цивільних прав та обов'язків (щодо надання дозволу на обробку їі персональних даних).

Об'єктивована форма згоди суб'єкта персональних даних повинна давати змогу зробити висновок про надання згоди та може бути вчинена у письмовій формі, здебільшого у вигляді окремого документу (згода на обробку персональних даних), або як одна 3 умов договору; шляхом конклюдентних дій, якщо його поведінка засвідчує волю на обробку персональних даних, зокрема, шляхом проставлення відмітки про надання дозволу на обробку своїх персональних даних під час реєстрації в інформаційно-телекомунікаційній системі суб’єкта електронної комерції.

3. Згода суб'єкта персональних даних відрізняється від інших підстав обробки персональних даних тим, що інші підстави обробки обтяжені додатковою умовою - «тестом на необхідність». Тобто, обробка персональних даних буде вважатися правомірною, якщо вона $є$ необхідною для досягнення цілей, зумовлених у відповідній підставі. Якщо ж обробка персональних даних виходить за межі такої необхідності, то для іï здійснення вже потрібна згода суб'єкта персональних даних.

Отримання згоди суб'єкта персональних даних не звільняє їх володільця від обов'язку дотримуватися загальних та особливих вимог до обробки персональних даних. Більше того, згода фізичної особи на обробку персональних даних не тягне за собою іiі відмову від прав суб'єкта персональних даних чи звуження їх змісту. Так само згода на обробку персональних даних не позбавляє та не обмежує можливості захисту персональних даних.

Стаття присвячена питанням виникнення підстав иивільних правовідносин щодо персональних даних. Важливою підставою виникнення изиільних правовідносин 
щодо персональних даних є згода суб'єкта персональних даних, яку слід розглядати як вияв можливості вільно визначати свою поведінку у сфері особистого життя, спрямовану на те, щзоб уповноважити володільия персональних даних на їх подальшої обробку, та забезпечує контроль суб'єкта персональних даних за ї обробкою. Згода суб'єкта персональних даних як юридичний факт слугує підставою для обробки таких даних.

Згода суб'єкта персональних даних має всі ознаки одностороннього правочину: $є$ дією особи (добровільним волевиявленням фізичної особи), спрямованою на набуття, зміну або припинення циивільних прав та обов'язків (щодо надання дозволу на обробку ї персональних даних). Об'єктивована форма згоди суб'єкта персональних даних повинна давати змогу зробити висновок про надання згоди та може бути виннена у письмовій формі, здебільшого у вигляді окремого документу, або як одна з умов договору; иляхом конклюдентних дій, якщо його поведінка засвідчує волю на обробку персональних даних, зокрема, шляхом проставлення відмітки про надання дозволу на обробку своїх персональних даних під час реєстрації в інформаційно-телекомунікаційній системі суб'єкта електронної комериії.

Згода суб'єкта персональних даних відрізняється від інших підстав обробки персональних даних тим, щзо інші підстави обробки обтяжені додатковою умовою «тестом на необхідність». Обробка персональних даних буде вважатися правомірною, якщо вона є необхідною для досягнення цүілей, зумовленuх у відповідній підставі. Якщо ж обробка персональних даних виходить за межі такої необхідності, то для ї̈ здійснення вже потрібна згода суб'єкта персональних даних.

Отримання згоди суб’єкта персональних даних не звільняе їх воло- дільияя від обов'язку дотримуватися загальних та особливих вимог до обробки персональних даних. Згода фізичної особи на обробку персональних даних не тягне за собою ї̈ відмову від прав суб'єкта персональних даних чи звуження їх змісту. Так само згода на обробку персональних даних не позбавляе та не обмежує можливості захисту персональних даних.

Ключові слова: персональні дані, підстави виникнення цивільних правовідносин, згода, обробка персональних даних.

Bielova Yu. Consent and other grounds for the appearence of civil legal relations regarding personal data

The paper is dedicated to issues on grounds for the appearence of civil legal relations regarding personal data. An important ground for the appearence of civil legal relations regarding personal data is consent of personal data subject. The consent of personal data subject has to be understood as a manifestation of opportunity for free determination of own behavior in the field of privat life that, on the one hand, is aimed to to authorize an owner of personal data for the futher processing and, on the other hand, provides a control of the personal data subject on its processing.

The consent of personal data subject as a juridical fact is a ground for processinf such data. The consent of personal data subject has all features of unilateral transaction as it is an action of a person (voluntary expression of the will of an individual) that is aimed at acquiring, changing or terminating civil rights and obligations (for granting permission to process her personal data).

Objective form of the consent of subject of personal data has to provide opportunity to conclude about consent, and can be committed: in writting, as a rule, as a particular document or as a one of the conditions of agreement; 
in the way of implicit actions where his behavior indicates a willingness to process personal data, particularly in the way of marking the permission to process their personal data during registration in the information and telecommunication system of the e-commerce entity.

The consent of personal data subject is different from other grounds of personal data processing as other grounds of processing are burdened with an additional condition - "a test of necessity". Personal data processing is lawful where it is necessary to achieve the objectives set out in the relevant grounds. Where the personal data processing is out of the frame of such necessaty, its realization demands the consent of personal data subject.

Obtaining a consent of personal data subject does not release their owner from the obligation to comply with the general and special requirements for the processing of personal data. The consent of individual for personal data processing does not entail its waiver of the rights of the data subject or the narrowing of their content. Similarly, consent to the processing of personal data does not deprive or limit the possibility of protection of personal data.

Key words: personal data, grounds for the appearence of civil legal relations, consent, personal data processing.

\section{Література}

1. Regulation (EU) 2016/679 of the European Parliament and of the Council of 27 April 2016 on the protection of natural persons with regard to the processing of personal data and on the free movement of such data, and repealing Directive 95/46/EC (General Data Protection Regulation). URL: http:// eur-lex.europa.eu/legalcontent / EN / TXT / $P D F /$ ? uri $=$ CELEX:32016R0679\&from $=E N$ M.

2. Cheung A. Moving beyond Consent for Citizen Science in Big Data Health Research. University of Hong Kong Faculty of Law Research Paper. 2017. № 006. URL: http: / / dx.doi.org / 10.2139/ssrn.2943185.
3. Hurd H. The Moral Magic of Consent. Legal Theory. 1996. Volume 2. Issue 2. P. 121-146.

4. Schermer B., Custers B. van der Hof S. The Crisis of Consent: How Stronger Legal Protection May Lead to Weaker Consent in Data Protection. Ethics and Information Technology. 2014. Volume 16, Issue 2. P. 171-182.

5. Романюк I. Особливості змісту та реалізації права на персональні дані в Україні та зарубіжних країнах. Вісник Київського національного університету імені Тараса Шевченка. Юридичні науки. 2013. Bun. 2. C. 102-106.

6. Посикалюк О.О. Особисті немайнові права фізичних осіб у романській, германській, англо-американській системах приватного права. К. : Науково-дослідний інститут приватного права і підприємництвва НАПрН України. 2011. 205 с.

7. Mantelero A. The Future of Consumer Data Protection in the E.U. Rethinking the "Notice and Consent" Paradigm in the New Era of Predictive Analytics. Computer Law and Security Review. 2014. Issue 30. P. 643-660.

8. Серебряник О.O. Інформація про особу як об'єкт цивільних прав: дис. канд. юрид. наук: 12.00.03 / O.O. Серебряник. Івано-Франківськ, 2016. 209 с.

9. Горпинюк О.П. Правова регламентація накопичення та використання приватної інформащї в Україні. Вісник Кримінологічної асоціації України. 2013. № 4. C. 214-226.

10. Серебряник О.О. Інформація про особу як об'єкт ицивільних прав : автореф. дис. канд. юрид. наук: 12.00.03; Івано-Франків. ун-т права ім. короля Данила Галицького. Івано-Франківськ, 2016. 20 с.

11. Захист персональних даних: правове регулювання та практичні аспекти. Бем М.В. та ін. Спільна програма Європейського Союзу та Ради Європи «Зміинення інформ. сусп-ва в Україні». Київ : K.I.C, 2015. 219 c.

12. Asociaciyn Nacional de Establecimientos Financieros de Crŭdito (ASNEF), Federaciyn de Comercio Electrynico y Marketing Directo (FECEMD) v. Administraciyn del Estado: Judgment of the Court of Justice of the European Union, 24 November 2011. URL: http:// eur-lex.europa.eu/ legal-content / EN/TXT/HTML/?uri $=C E L$ EX:62010CJ0468\&from $=E N$.

13. Opinion 15/2011 on the definition of consent. Adopted on 13 July 2011. URL: http: / / ec.europa.eu/justice/policies / privacy/docs/wpdocs/2011/wp187en.pdf. 